\title{
A familiar tumour, a common infection and an unforeseen affair
}

\author{
Sandesh Madi, Vivek Pandey, Varun Takkallapally Rao, Kiran Acharya
}

Department of Orthopaedics, Kasturba Medical College, Manipal, Karnataka, India

\section{Correspondence to} Dr Sandesh Madi, sandesh.madi@gmail.com

Accepted 12 December 2015

\section{DESCRIPTION}

A 33-year-old man, a carpenter, presented with a non-traumatic dull aching pain of 4 months duration in the right groin. Clinical examination was unremarkable, except for tenderness over the posteromedial aspect of the groin. A pelvic radiograph showed a bony outgrowth in the lesser trochanteric region favouring the diagnosis of a solitary osteochondroma (figure 1). MRI revealed a pedunculated bony excrescence with a thin cartilaginous cap, arising close to the lesser trochanter, surrounded by a well-defined fluid signal intensity suggestive of a collection (figure 2). All serological tests were essentially normal (apparently immunocompetent).

The tumour was excised (figure 3) using a dual surgical method to the hip: an anteromedial
Ludloff's approach (in the figure-of-four position) followed by a posterolateral approach (in lateral decubitus position). Intraoperatively, the bursal fluid appeared thick and 'granular'. The fluid was sent for staining, culture and PCR analysis for tuberculosis. Postoperatively, a graduated weightbearing protocol was followed. Nested PCR for tuberculosis from the bursal fluid was positive (however, bursal tissue histopathology was negative). Histopathological assessment of the tumour confirmed it as being benign (figure 4). A four-drug antitubercular regime was started. At 14 months of follow-up, the patient is asymptomatic and there is no evidence of tumour recurrence.

The presentation of an osteochondroma lesion in the proximal femur is infrequently encountered as most are usually asymptomatic. ${ }^{1}$ Pain arising from a

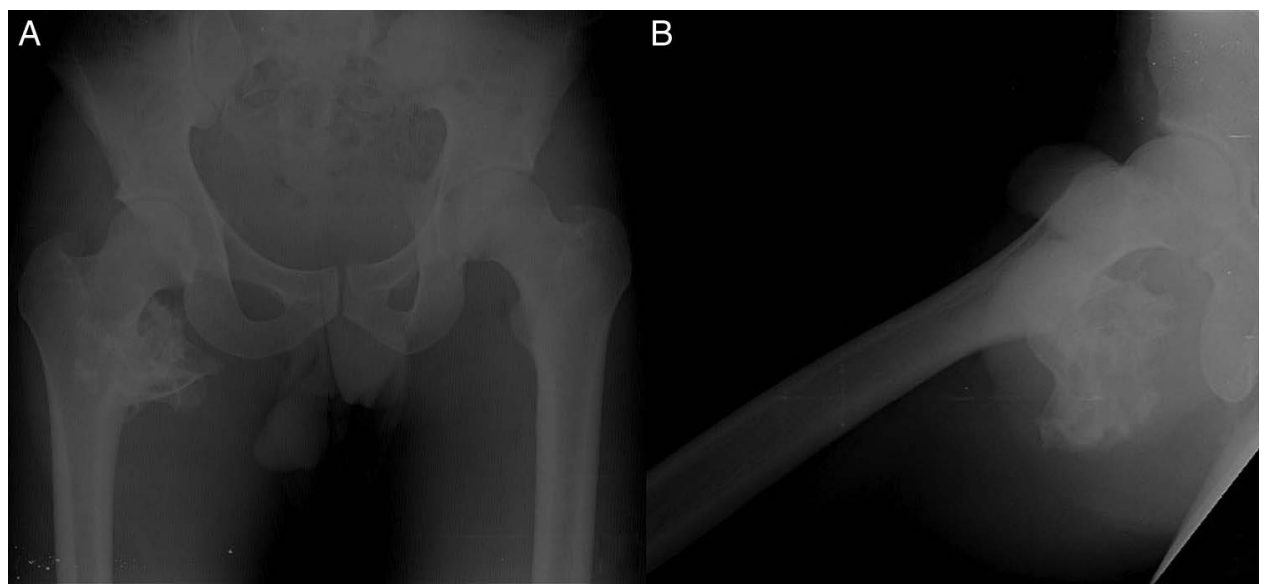

Figure 1 Preoperative plain radiograph $(A)$ anteroposterior view of the pelvis and (B) lateral view of the right hip.

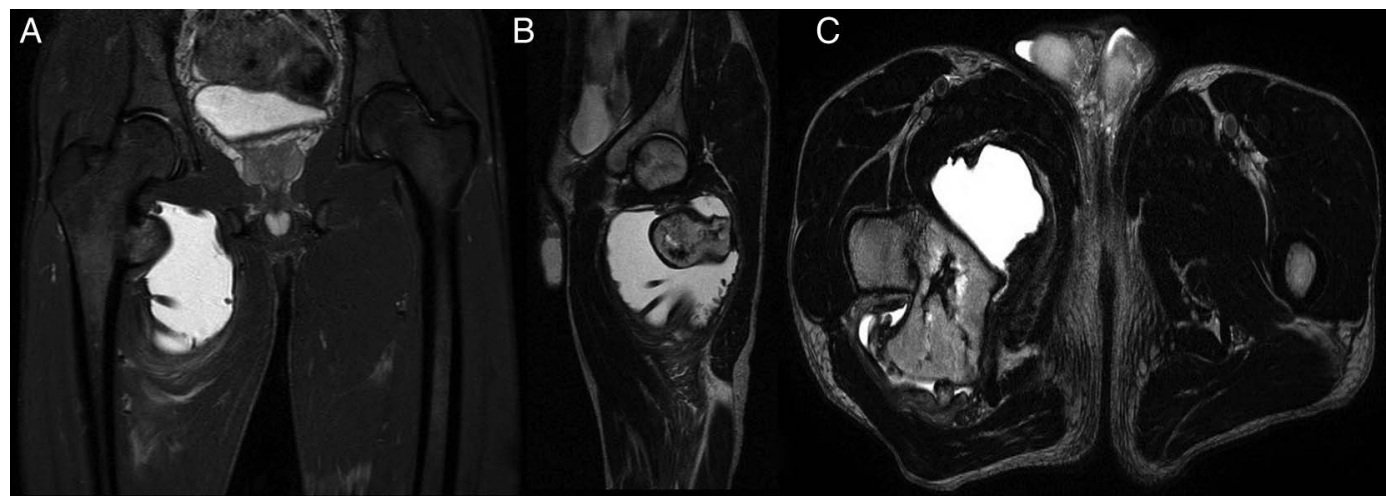

Figure 2 MRI of the right hip (A) coronal, (B) sagittal, (C) axial views-showing the extent of bony outgrowth and a well-defined fluid signal intensity (a few septae within and a uniform peripheral enhancement) is seen with epicentre in the adductor compartment of the right thigh and encasing the bony outgrowth of the lesser trochanter. 


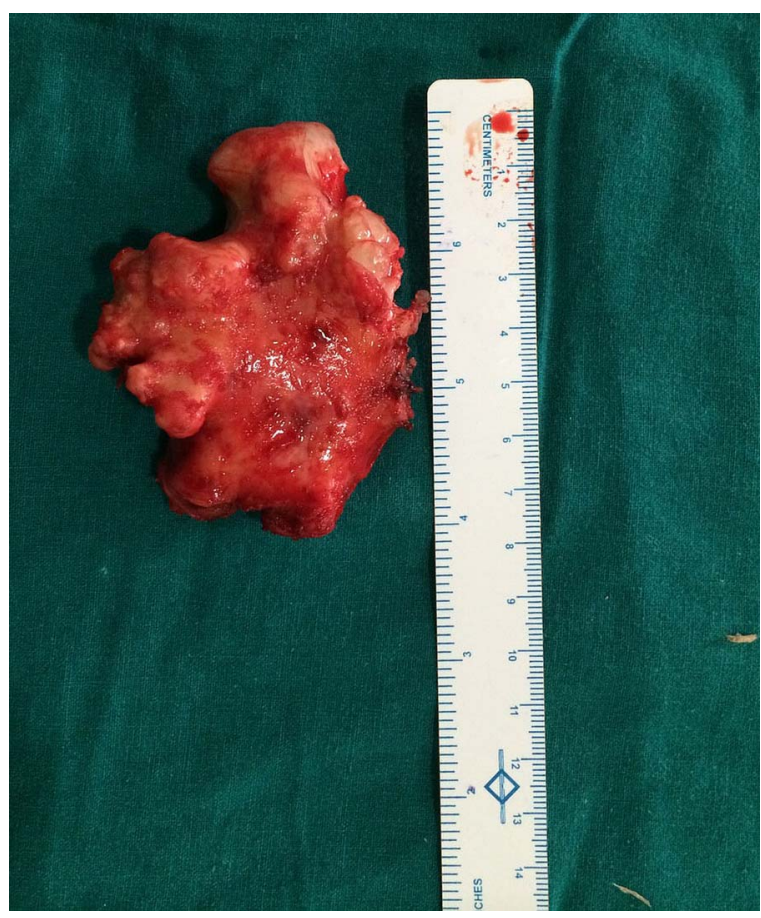

Figure 3 Gross specimen of the excised tumour.

pre-existing quiescent osteochondroma could be mostly from bursitis or, rarely, malignant transformation. The current lesion extended from an anteromedial to a posterolateral aspect of the

\section{Learning points}

- A solitary osteochondroma arising near the lesser trochanter is rare, diagnosed mostly after becoming clinically symptomatic.

- Osteochondroma with concomitant tubercular bursitis is an unforeseen affair.

- In uncommon sites and unusual presentations, suspect tuberculosis, especially in endemic belts.

- Complete surgical excision of an extensive lesion can be accomplished by a dual approach without dislocating the hip.

- Close follow-up is essential to monitor treatment besides watching out for recurrence.

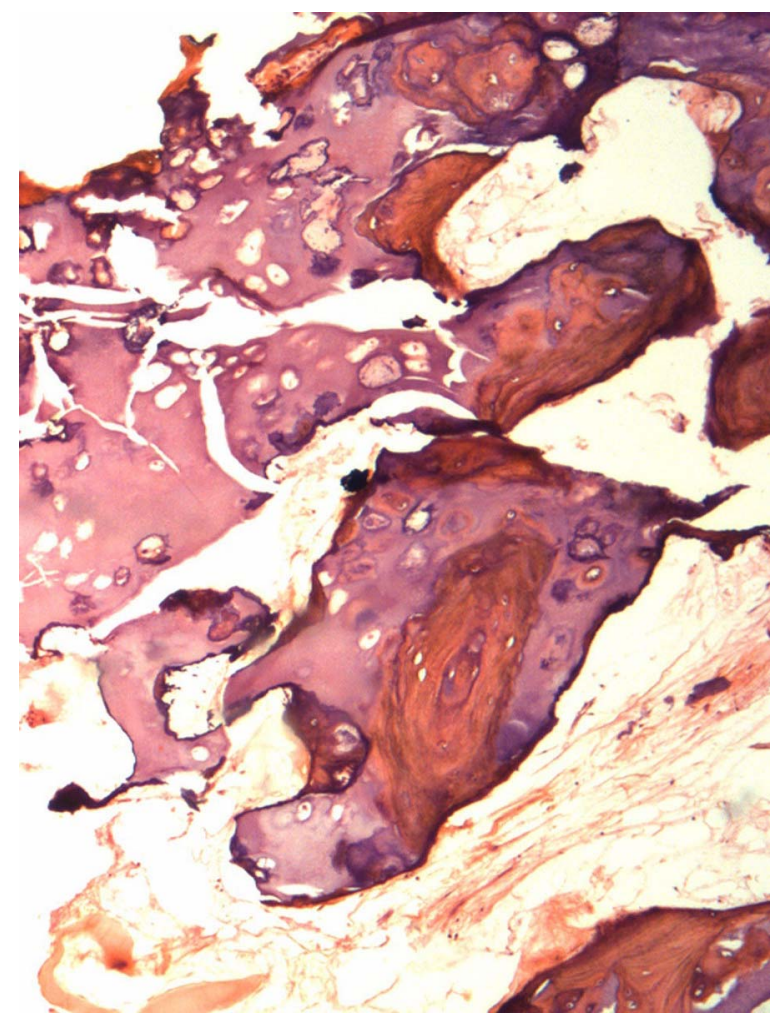

Figure 4 Low power microscopy showing lobules of hyaline cartilage with endochondral ossification (H\&E stain).

hip in a curvilinear fashion, compelling us to perform extensive surgical excision via a dual approach to the hip. A microbiological work up for tuberculosis for bursal fluid was performed owing to a high index of suspicion (granular appearance). An excision is a successful form of treatment for symptomatic osteochondromas with low morbidity. ${ }^{2}$

Competing interests None declared.

Patient consent Obtained.

Provenance and peer review Not commissioned; externally peer reviewed.

\section{REFERENCES}

1 Rajaram Manoharan S, Gopinathan N, Vishwanathan V, et al. Surgical excision of a large sessile osteochondroma of the lesser trochanter of femur: a case report. Webmed Cent Orthop 2010;1:WMC001237.

2 Bottner F, Rodl R, Kordish I, et al. Surgical treatment of symptomatic osteochondroma. A three-to eight-year follow-up study. J Bone Joint Surg Br 2003;85:1161-5.

Copyright 2015 BMJ Publishing Group. All rights reserved. For permission to reuse any of this content visit http://group.bmj.com/group/rights-licensing/permissions.

BMJ Case Report Fellows may re-use this article for personal use and teaching without any further permission.

Become a Fellow of BMJ Case Reports today and you can:

- Submit as many cases as you like

- Enjoy fast sympathetic peer review and rapid publication of accepted articles

- Access all the published articles

- Re-use any of the published material for personal use and teaching without further permission

For information on Institutional Fellowships contact consortiasales@bmjgroup.com

Visit casereports.bmj.com for more articles like this and to become a Fellow 